\title{
УДК 911.2:528.94
}

\section{ПОЧВЫ БАЙКАЛЬСКОГО РЕГИОНА И ПРИЛЕГАЮЩИХ ТЕРРИТОРИЙ}

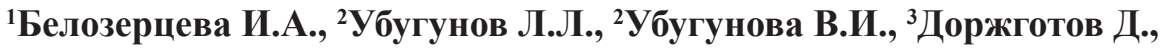

${ }^{2}$ Гынинова А.Б., ${ }^{2}$ Убугунов В.Л., ${ }^{1}$ Сороковой А.А., ${ }^{2}$ Бадмаев Н.Б.

${ }^{1}$ ФАНО России ФГБУН Институт географии им. В.Б. Сочавы СО РАН, Иркутск, e-mail: belozia@mail.ru;

${ }^{2}$ ФАНО России ФГБУН Институт общей и экспериментальной биологии СО РАН, Улан-Удэ;

${ }^{3}$ Институт географии и геоэкологии академии наук Монголии, Улан-Батор

На основе результатов многолетних исследований проведено картографирование почв Байкальского региона и прилегающих территорий масштаба 1:5000000. При составлении почвенной карты использованы разнообразные карты по рельефу, геоморфологии, геологии, растительности, климату, почвам, аэро- и космические снимки, а также материалы почвенно-географических исследований авторов. Карта составлена в программе MapInfo. Большая протяженность исследуемого региона предопределяет широтные изменения климатического фактора и связанного с ним почвенного и растительного покрова. Географические закономерности формирования почв весьма сложны, вследствие того, что на мало выраженную горизонтальную зональность накладывается высотная поясность горных систем. Неоднородное геоморфологическое и литологическое строение, контрастная биоклиматическая обстановка способствуют формированию различных типов почв. Специфичность экологических условий почвообразования в некоторых районах исследуемой территории определяет самобытность почв. Например, формирование буроземов грубогумусовых в условиях Южного Прибайкалья. Маломощные неполнопрофильные почвы отделов литоземов, слаборазвитого и органо-аккумулятивного, развиты во всех высотных зонах. Нормально развитые почвы с полным набором всех генетических горизонтов распространены в основном в таежной зоне и представлены разными типами криоземов, альфегумусового и структурно-метаморфического отделов; а в степной зоне полнопрофильные почвы представлены отделами аккумулятивно-гумусового, аккумулятивно-карбонатного, светлогумусового, структурно-метаморфического и галоморфного. Суровые климатические условия и горный характер Байкальского региона обусловливают слабую интенсивность процессов физического и химического выветривания. Изложенные материалы показывают сложное устройство поверхности исследуемой территории, разнообразие литологии и контрастность биоклиматических условий, определяющих своеобразие почвенного покрова. Создание почвенной карты Байкальского региона и прилегающих территорий представляет собой важный этап в развитии почвенной науки России и Монголии.

Ключевые слова: почвы, разнообразие, картографирование, Байкальский регион

\section{SOILS OF THE BAIKAL REGION AND ADJACENT TERRITORIES}

${ }^{1}$ Belozertseva I.A., ${ }^{2}$ Ubugunov L.L., ${ }^{2}$ Ubugunova V.I., ${ }^{3}$ Dorzhgotov D., ${ }^{2}$ Gyninova A.B., ${ }^{2}$ Ubugunov V.L., ${ }^{1}$ Sorokovoy A.A., ${ }^{2}$ Badmaev N.B.

${ }^{1}$ V.B. Sochava Institute of Geography SB RAS, Irkutsk, e-mail: belozia@mail.ru;

${ }^{2}$ Institute of the general and experimental biology SB RAS, Ulan-Ude;

${ }^{3}$ Institute of geography and geoecology of an academy of sciences of Mongolia, Ulaanbaator

On the basis of long-term research in Russia and Mongolia, a map of soils of the Baikal region and adjacent territories at a scale of 1:5000 000 has been compiled. Various cartographic data on soils, geology, geomorphology, forest, vegetation, climate, topography, aerial and space imagery, field studies of the authors were used for the map. It has been developed using MapInfo Software. The great extent of the region determines the latitudinal changes in the thermal factor and the soil and vegetation cover associated with it. Geographic patterns of soil cover formation are extremely complex, since altitude-vertical zonality is superimposed on the weakly expressed latitudinal zoning. The heterogeneity of the geomorphology and lithology, the contrast of the bioclimatic environment contribute to the formation of various soil types. Specific ecological conditions of pedogenic process in some areas of the Lake Baikal basin define the originality of soils, for example, forming of coarse-humus burozems in the Southern Baikal region. In all high-altitude zones, small-power, incomplete profile soils of departments of underdeveloped, lithozem and organic-accumulative soils are common. The full-profile soils in the taiga zone are mainly represented by different types of soils such as cryosols, alfa-humus and structural-metamorphic soils, in the steppe - accumulative-humus, light-humus, accumulative-carbonate, structural-metamorphic, halomorphic soils. The mountain relief and sharply continental climate of the region are the cause of weak intensity of chemical and physical weathering. The stated data indicate the complex structure of the earth surface of the region, different lithology and contrast bioclimatic conditions that determine the originality of the soil cover. The development of a soil map of the Baikal region is an important stage of the soil science progress in Russia and Mongolia.

Keywords: soils, variety, mapping, Baikal region

Целью исследования является картографирование почв Байкальского региона с использованием единой классификации почв для территории России и Монголии. Район исследования находится в бассейне самого глубокого и крупнейшего рифтового озера планеты - Байкала. Часть ее входит в состав ООПТ (национальные парки, заповедники, заказники). Протяженность составляет более 6000 км с севера на юг, что предопределяет широтные изменения климатического фактора и связанного с ним почвенного 
и растительного покрова. Байкальский регион включает Республику Бурятия, Иркутскую область, Забайкальский край, а также аймаки северной Монголии. Особенности геологического строения обусловлены тем, что территория исследования находится на границе Сибирской платформы и Центрально-Азиатского подвижного пояса. Большие площади в Монголии и Западном Забайкалье заняты продуктами разрушения Ангаро-Витимского, Хангайского и Хэнтэйского батолитов. В Иркутской области выделяются красноцветные карбонатно-силикатные породы. Рельеф представляет собой целое плиоцен-четвертичное основание. На фоне общего поднятия в это время происходили опускания отдельных элементов, которые привели к образованию впадин-грабенов. Минимальная абсолютная высота составляет 460 м над ур. м. - урез оз. Байкал. Максимальная абсолютная высота находится в Хангае (3539 м над ур. м.). Преобладающим типом климата в Республике Бурятия, Иркутской области, Забайкальском крае и Монголии является резко континентальный, на побережье озера Байкал он подходит к приморскому. Зимняя температура воздуха на берегах южной оконечности 03. Байкал в среднем на $5^{\circ} \mathrm{C}$ выше, а в летнее на столько же ниже, чем в отдаленных районах [1]. До 1400 мм осадков в год выпадает на западных и северо-западных склонах, обращенных к преобладающим ветрам. Наименьшее количество (200-300 мм) осадков в год выпадает в межгорных котловинах Забайкалья и Монголии, а также в степных районах западного побережья оз. Байкал (Приольхонье). От 400 до 700 мм осадков в год поступает на наветренные склоны вторичных хребтов и внутренние районы нагорий [1]. Растительность Байкальского региона представлена сообществами гольцового (высокогорного), таёжного (бореального) и степного типов. Таежная растительность в Байкальском регионе преобладает. В переходных зонах таёжной и островной степной растительности распространены лесостепные комплексы. Степи в основном наблюдаются на южных склонах гор и возвышенностей, а лесные таёжные, местами остепнённые сообщества - на восточных и северных склонах. На юге бассейна оз. Байкал и в северной Монголии преобладает степная растительность.

\section{Материалы и методы исследования}

При картографировании (рисунок) использованы разнообразные карты по рельефу, геоморфологии, геологии, растительности, климату, космические снимки, опубликованные монографии [2-4] и статьи $[5,6]$, результаты многолетних почвенно-географических исследований авторов [7, 8].

Крупномасштабные почвенно-географические исследования на территории бассейна оз. Байкал (Монголия, Россия) были проведены в 1960-1980 гг. Н.А. Ногиной (1964), В.П. Мартыновым (1965), К.А. Уфимцевой (1967), Д. Доржготовым (1973), В.А. Кузьминым (1973), И.А. Соколовым, В.О. Таргульяном (1976). Основные закономерности обобщены в почвенных картах Монгольской Народной Республики и Бурятии. Эти карты были созданы на различной методологической основе.

В основу карты легли материалы и принципы ранее созданной авторами карты «Почвы бассейна озера Байкал» [7]. Также были использованы почвенные карты: Иркутской области, разработанной В.А. Кузьминым [6], Монголии - Д. Доржготовым и О. Батхишиг [5], Республики Бурятия - сотрудниками Института общей и экспериментальной биологии СО PAH [8]. Карта создана авторами в программе MapInfo. В отличие от предыдущих карт использована новая классификация и диагностика почв России $[9,10]$. На почвенной карте осуществлено интегрирование современной информации по почвам и почвенному покрову бассейна о3. Байкал на единой методологической основе и принципах классификации.

В легенде карты приводятся комбинации почв различных контуров. Ассоциации почв контуров характеризуются разнородностью почвообразующих пород (мозаики), различным мезо- (сочетания) и микрорельефом (комплексы). Преобладающая почва расположена первой в легенде, затем - сопутствующие и встречающиеся. Большая часть почв представлена на уровне типа, иногда подтипа.

\section{Результаты исследования и их обсуждение}

Рассмотрим преобладающие почвы Байкальского региона (включая территорию Монголии) соответственно их современной классификации $[9,10]$. С относительно большой высотой в горах (2000-3000 м над ур. м.) связано изменение гидротермических условий и проявление вертикальной зональности почв. В высоко- 
горьях преобладают: литоземы, петроземы гольцов и тундр; литоземы перегнойнотемногумусовые и темногумусовые субальпинотипных и альпинотипных лугов; торфяно-литоземы, подбуры и подзолы под кедрово-стланиковыми зарослями и подгольцовыми редколесьями. Распространен кустарниковый и мохово-лишайниковый покров, а древесная растительность занимает небольшую часть территории. В Байкало-Патомском нагорье преобладают редколесья, в почвенном покрове которых развиты подзолы. В Восточном Саяне редколесья не составляют больших ареалов. Большие контуры образованы тундрами и лугами с литоземами темногумусовыми и перегнойно-темногумусовыми почвами. Высокогорья Станового нагорья занимают большую площадь, при меньшей абсолютной высоте.

Заросли кедрового стланика с литоземами, петроземами, подбурами и подзолами наблюдаются среди каменистых россыпей на хребтах Прибайкалья и Станового нагорья. Почвы с элювиально-иллювиальным и недифференцированным профилями горной тайги развиты в северо-восточном и юго-западном Прибайкалье. На Байкальском хребте и Байкало-Патомском нагорье распространены подзолы и подбуры, встречаются торфяно-подзолы и торфяно-подбуры. При более разнообразных природных условиях Восточного Саяна, кроме подзолов, сформировались подзолистые и дерново-подзолистые почвы. Под темнохвойными пихтовыми лесами при мощном снеговом покрове, который способствует непромерзанию почв, встречаются буроземы грубогумусовые. До 1000 мм и более осадков в год выпадает в высокогорьях, при этом мощность снега доходит до 1,9 м. Буроземы грубогумусовые также встречаются в среднегорном поясе Хамар-Дабана.

На крутых склонах, направленных к оз. Байкал, распространены петроземы. Торфяно-подбуры и подбуры встречаются на основных породах, которые редко встречаются в горной тайге. Темногумусовые, подзолистые и дерново-подзолистые остаточно-карбонатные почвы формируются на карбонатных породах.

Почвы таежных ландшафтов предгорий и плато занимают средние и низкие местоположения с осадочными породами относительно небольшой мощности. На рыхлых породах Лено-Ангарского плато у верхней границы таежного пояса рас- пространены подзолистые, дерново-подзолистые почвы, а на вершине Орленгского плато (более 1200-1300 м), занятого кедровым редколесьем с лишайниковым покровом, отчетливо выделяются сочетания подзолов, подбуров и торфяно-подбуров глеевых. На кислых силикатных отложениях доминируют сочетания дерново-подзолистых почв с подзолистыми. На севере Байкальского региона (бассейн Нижней Тунгуски) под среднетаежными лиственничниками на плоских поверхностях распространены криоземы и торфяно-криоземы.

В предгорных сухих степях Приольхонья встречаются каштановые и светлогумусовые почвы. На Приольхонском плато сохранилась «добайкальская» геоморфологическая обстановка с прерывистыми глубоковыветрелыми породами позднемелового-раннепалеогенового возраста. Благодаря стабильному положению поверхности Приольхонского тектонического блока и сухим условиям хорошо сохранился древний рельеф плато. Малое количество атмосферных осадков и большая водопроницаемость грунтов и почв осложняют условия произрастания растений. Черноземы глинисто-иллювиальные гидрометаморфизованные, гумусово-гидроморфические и каштановые гидрометаморфизованные почвы сформировались в долинах и падях временных водотоков Приольхонья. Серогумусовые почвы развиты в Приольхонском плато и предгорьях Приморского хребта.

На Иркутско-Черемховской равнине, в Предбайкальской впадине и в восточной части Канско-Рыбинской равнины развиты почвы степных, лесостепных и таежных ландшафтов. От Иркутского водохранилища до западной границы Иркутской области имеют распространение серые почвы. Они нередко граничат с дерново-подзолистыми почвами. Дерново-подзолистые почвы формируются на водоразделах и приводораздельной территории, а серые - на склонах. На повышенной части Иркутско-Черемховской равнины, переходящей в Лено-Ангарское плато встречаются темногумусовые почвы с черноземами на доломитах, известняках и красноцветных карбонатносиликатных отложениях. Черноземы на террасах рек Ангары, Куды и их притоков сформировались в условиях «котловинного» эффекта с предгорной (аридно-теневой) зональностью. 
В высокогорьях Хамар-Дабана, Баргузинского, Верхне-Ангарского и Муйского хребтов распространены петроземы, торфяно-литоземы и литоземы грубогумусные. Грубогумусовые, перегнойные и перегнойно-темногумусовые почвы сформировались под субальпийскими лугами. Подбуры глеевые развиты на северных склонах в относительно пониженных элементах рельефа и на участках с почвообразующими породами тяжелого гранулометрического состава [8].
В горно-таежной зоне Забайкалья встречаются различные почвы, что связано с проявлением горной поясности, наличием многолетней мерзлоты и разной экспозицией склонов. В этой зоне преобладают дерново-подбуры, подбуры, перегнойно-темногумусовые, перегнойные, буроземы грубогумусовые и серогумусовые почвы. Серые метаморфические почвы сформировались на подгорных участках котловин и северных склонах сопок лесостепной зоны.

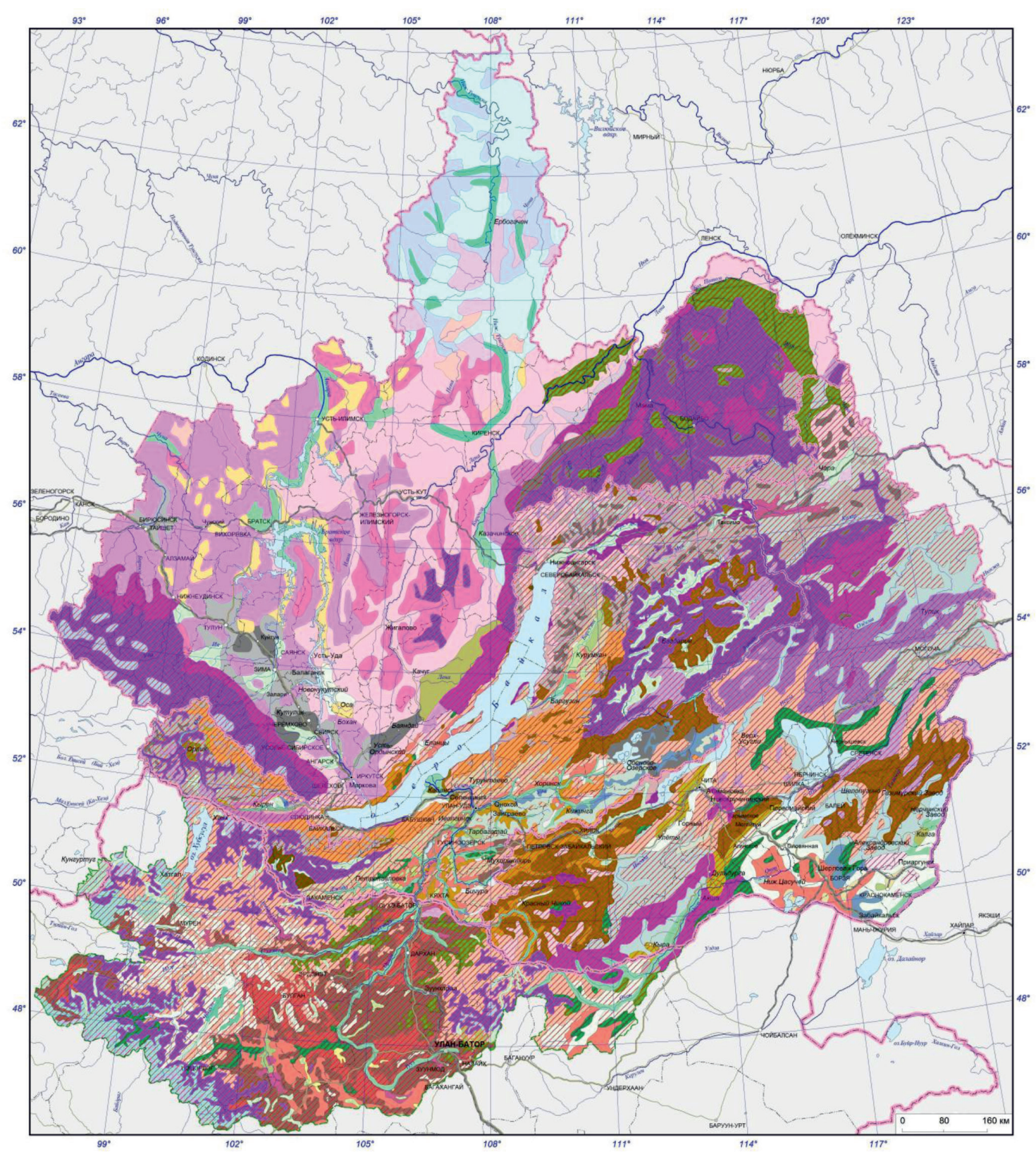

Почвы Байкальского региона 


\begin{tabular}{|c|c|c|c|}
\hline & Основные почвы & $\begin{array}{c}\text { Сопутствующие (около 15-20 \% } \\
\text { к площади контура) }\end{array}$ & Встречающиеся (около 5-10 \%) \\
\hline \multicolumn{4}{|c|}{ Почвы горных территорий } \\
\hline & литоземы, петроземы & криоземы, подбуры & глееземы, подзолы \\
\hline WDIDllas & литоземы & петроземы & подбуры \\
\hline WIIIIIIIS & литоземы грубогумусовые & глееземы, подбуры & петроземы \\
\hline WIIIISISA & $\begin{array}{l}\text { литоземы перегнойно- } \\
\text { темногумусовые }\end{array}$ & глееземы & карбо-литоземы темногумусовые \\
\hline VIIIIIIILS & литоземы темногумусовые & литоземы серогумусовые & литоземы темногумусовые \\
\hline YIIIIIIIL & глееземы & торфяно-глееземы & торфяно-литоземы \\
\hline YIIIIIIILL & торфяно-глееземы & торфяно-литоземы & торфяно-подбуры глеевые \\
\hline & карбо-литоземы темногумусовые & $\begin{array}{l}\text { карбо-литоземы перегнойно- } \\
\text { темногумусовые }\end{array}$ & карбо-литоземы перегнойные \\
\hline & карбо-литоземы перегнойные & карбо-литоземы темногумусовые & $\begin{array}{l}\text { карбо-литоземы перегнойно- } \\
\text { темногумусовые }\end{array}$ \\
\hline & перегнойно-темногумусовые & перегнойно-криометаморфические & перегнойные \\
\hline & криоземы & подбуры & торфяно-литоземы \\
\hline & криоземы грубогумусовые & криоземы & торфяно-криоземы \\
\hline Wlla & торфяно-криоземы & торфяно-подбуры & торфяно-глееземы \\
\hline & подзолистые & подзолы & дерново-подзолистые \\
\hline & дерново-подзолы & подзолы & подзолистые \\
\hline & подбуры грубогумусированные & дерново-подбуры, сухоторфяно-подбуры & буроземы грубогумусовые \\
\hline & подбуры оподзоленные & подбуры иллювиально-железистые & подбуры иллювиально-гумусовые \\
\hline & подбуры, буроземы грубогумусовые & дерново-подбуры & подзолы \\
\hline YIDIIIIILa & подбуры, подзолы & дерново-подзолы & дерново-подбуры \\
\hline WUIIIIIIA & буроземы & подбуры & подзолы \\
\hline WUIIIIIIs & подбуры и грубогумусовые & $\begin{array}{l}\text { дерново-подзолы и буроземы } \\
\text { грубогумусовые }\end{array}$ & подзолы \\
\hline WIIIIIIIA & дерново-подбуры & серогумусовые & $\begin{array}{l}\text { литоземы серогумусовые и } \\
\text { петроземы гумусовые }\end{array}$ \\
\hline & темногумусовые типичные & темногумусовые метаморфизованные & темногумусовые глееватые \\
\hline & темногумусовые метаморфизованные & темногумусовые глееватые & темногумусовые остаточно-карбонатные \\
\hline WIIDIIIL & светлогумусовые & каштановые & серогумусовые \\
\hline VDOPDIIA & темногумусовые остаточно-карбонатные & черноземы дисперсно-карбонатные & темногумусовые метаморфизованные \\
\hline YIIIIIIIIL. & черноземы дисперсно-карбонатные & черноземы гидрометаморфизованные & каштановые \\
\hline YIIIIIIIIL & черноземы гидрометаморфизованные & черноземовидные & темногумусовые \\
\hline & каштановые & каштановые гидрометаморфизованные & черноземы дисперсно-карбонатные \\
\hline & криоаридные & каштановые & криогумусовые \\
\hline
\end{tabular}

Легенда к карте «Почвы Байкальского региона» (начало) 


\begin{tabular}{|c|c|c|}
\hline Основные почвы & $\begin{array}{l}\text { Сопутствующие (около } 15-20 \% \\
\text { к площади контура) }\end{array}$ & Встречающиеся (около 5-10 \%) \\
\hline \multicolumn{3}{|c|}{ Почвы высоких равнин и межгорных понижений } \\
\hline подзолы & дерново-подзолы & подзолистые \\
\hline дерново-подзолистые & подзолистые & дерново-подбуры оподзоленные \\
\hline $\begin{array}{l}\text { подзолистые иллювиально- } \\
\text { гумусово-железистые }\end{array}$ & дерново-подзолистые & торфяно-подзолисто-глеевые \\
\hline подзолисто-глеевые & подзолы глеевые & дерново-подзолы глеевые \\
\hline подзолистые типичные & подзолистые остаточно-карбонатные & дерново-подзолистые \\
\hline $\begin{array}{l}\text { дерново-подзолистые } \\
\text { остаточно-карбонатные }\end{array}$ & дерново-подзолистые & темногумусовые, серогумусовые \\
\hline псаммоземы гумусовые & светлогумусовые & псаммоземы оподзоленные \\
\hline дерново-подзолы глеевые & дерново-подзолисто-глеевые & дерново-подзолы глееватые \\
\hline дерново-подбуры и дерново-серые & псаммоземы гумусовые & темногумусовые \\
\hline $\begin{array}{l}\text { дерново-подбуры и псаммоземы } \\
\text { гумусовые }\end{array}$ & подбуры & псаммоземы \\
\hline подбуры & дерново-подбуры & буроземы \\
\hline дерново-серые & серые метаморфические & серогумусовые \\
\hline серые метаморфические & дерново-серые & серогумусовые \\
\hline серые & темно-серые & серые метаморфические \\
\hline темно-серые & серые & серые метаморфические \\
\hline $\begin{array}{l}\text { дерново-подзолистые остаточно- } \\
\text { карбонатные, темногумусовые }\end{array}$ & $\begin{array}{l}\text { дерново-подзолистые, } \\
\text { буроземы темные }\end{array}$ & карбо-литоземы темногумусовые \\
\hline $\begin{array}{l}\text { перегнойно-темногумусовые, } \\
\text { темно-серые }\end{array}$ & $\begin{array}{l}\text { темногумусовые, карбо-литоземы } \\
\text { перегнойно-темногумусовые }\end{array}$ & $\begin{array}{l}\text { дерново-подзолистые в т.ч. } \\
\text { остаточно-карбонатные }\end{array}$ \\
\hline гумусово-гидрометаморфические & темногумусовые & перегнойно-темногумусовые \\
\hline перегнойно-глеевые & перегнойно-квазиглеевые & перегнойно-гумусовые глеевые \\
\hline черноземы квазиглеевые & черноземы гидрометаморфизованные & $\begin{array}{l}\text { черноземы глинисто-иллювиальные } \\
\text { квазиглеевые }\end{array}$ \\
\hline черноземовидные & темногумусовые метаморфизованные & $\begin{array}{l}\text { черноземы текстурно-карбонатные } \\
\text { квазиглеевые }\end{array}$ \\
\hline $\begin{array}{l}\text { черноземы дисперсно-карбонатные, } \\
\text { черноземы глинисто-иллювиальные }\end{array}$ & черноземы гидрометаморфизованные & черноземовидные \\
\hline черноземы текстурно-карбонатные & каштановые & каштановые гидрометаморфизованные \\
\hline каштановые & $\begin{array}{l}\text { криоаридные, каштановидные, } \\
\text { черноземовидные }\end{array}$ & $\begin{array}{l}\text { каштановые гидрометаморфизованные, } \\
\text { темногумусовые }\end{array}$ \\
\hline каштановые гидрометаморфизованные & каштановые турбированные & каштановые типичные \\
\hline торфяные эутрофные & торфяно-глееземы & перегнойно-глеевые \\
\hline торфяно-криоземы & криоземы & торфяные эутрофные \\
\hline торфяно-глееземы & торфяно-криоземы & торфяные эутрофные \\
\hline аллювиальные серугумусовые & $\begin{array}{l}\text { аллювиальные темногумусовые глеевые, } \\
\text { слоистые, перегнойно-глеевые }\end{array}$ & $\begin{array}{l}\text { аллювиальные торфяно-глеевые, } \\
\text { торфяно-криоземы глееватые }\end{array}$ \\
\hline $\begin{array}{l}\text { гумусово-гидрометаморфические } \\
\text { засоленные, перегнойно- } \\
\text { гидрометаморфические засоленные }\end{array}$ & $\begin{array}{l}\text { гумусово-гидрометаморфические } \\
\text { солонцеватые }\end{array}$ & $\begin{array}{l}\text { перегнойно-гидрометаморфические } \\
\text { солонцеватые }\end{array}$ \\
\hline аллювиальные торфяно-глеевые & торфяно-криоземы глееватые & $\begin{array}{l}\text { аллювиальные перегнойно-глеевые, } \\
\text { слоистые }\end{array}$ \\
\hline солончаки, солонцы & $\begin{array}{l}\text { светлогумусовые засоленные, каштановые } \\
\text { засоленные (солонцеватые) }\end{array}$ & темногумусовые засоленные \\
\hline серо- и светлогумусовые & псаммоземы & дерново-подбуры \\
\hline пески & псаммоземы гумусовые & псаммоземы \\
\hline
\end{tabular}

Легенда к карте «Почвы Байкальского региона» (окончание) 
Черноземы развиты под настоящими и луговыми степями Забайкалья. Большие контуры этих почв находятся на северных склонах Кударинской гряды, хребтов Боргойский, Моностойский, Малого Хамар-Дабана, а также на южных склонах Заганского хребта и на Тугнуйском хребте. В северном Забайкалье черноземы встречаются фрагментарно по долинам рек Уда и Итанцы, на северо-западных склонах Унэгэтэйского хребта. Каштановые и светлогумусовые почвы сформировались в сухой степи. Они развиты на террасах долин крупных рек, в Удинской, Иволгинской, Гусиноозерской, Боргойской, Киранской котловинах, а также на южных склонах хребтов. Северная граница степных почв находится в Баргузинской котловине. На водоразделах высоких увалов развиты литоземы. Псаммоземы гумусовые и светлогумусовые почвы сформировались в сухостепной зоне на эоловых песчаных отложениях, например на боровых песках в междуречье ЧикойХилок и Селенга-Чикой [8].

Широкое распространение многолетней мерзлоты, горный характер рельефа, разнообразие типов растительности и почвообразующих пород обусловило большую неоднородность почвенного покрова Витимского плоскогорья и Северного Забайкалья. Большая часть данной территории имеет сплошной тип распространения криолитозоны, и поэтому здесь преобладают мерзлотные почвы. Под лиственничными лесами и редколесьями преимущественно с подлеском из ерника на хребтах распространены подзолистые почвы и криоземы. Подбуры грубогумусовые сформировались на хребтах на южной границе криолитозоны под лиственничной тайгой с ерниковыми зарослями. Серые и серые метаморфические почвы развиты в Еравнинской котловине под березово-лиственичными лесами с ерниками. Черноземы квазиглеевые формируются в луговостепных ландшафтах приозерных равнин. Такие же закономерности структуры почвенного покрова характерны для ИваноАрахлейской, Ундино-Даинской, Нерчинской, Приаргунской лесостепи Восточного Забайкалья. На средневысотных хребтах Восточного Забайкалья под лиственничнососновыми лесами встречаются подбуры грубогумусовые и оподзоленные, на южной границе с Монголией - подзолы. Под пижмовыми и типчаковыми сообществами степных и сухостепных ландшафтов юго- восточного Забайкалья вблизи границы с Монголией и Китаем формируются черноземы и каштановые почвы. В районе Торейских озер встречаются солончаки.

В Джидинский горный район (10001800 м) входит верхнее и среднее течение p. Джида. Для этого района характерен полный спектр почвенно-растительных поясов. В верховьях рек распространены карболитоземы темногумусовые, литоземы грубогумусовые. Под горно-таежными лиственничниками (1300-1800 м) формируются криоземы и подбуры, в местах с застойным увлажнением - торфяно-литоземы. На высотах 1000-1300 м встречаются подбуры, дерново-подбуры и буроземы грубогумусные. В долинах рек Джида, Ур-Гол, Эгийн-Гол, Селенга распространен степной пояс с черноземами, темногумусовыми остаточно-карбонатными и каштановыми почвами. В котловинах и низкогорной части Джидинского и Хэнтэй-Чикойского горных районов получают развитие черноземы, каштановые, светлогумусовые, а в долинах рек - аллювиальные почвы, местами солончаки и солонцы. В низкогорье бассейнов рек Чикой и Хилок сформировались дерново-подзолы, дерново-подбуры, подзолы, серые метаморфические, черноземы, каштановые, аллювиальные и засоленные почвы.

В северной Монголии находится Хангайская почвенно-биоклиматическая область. Южная граница этой области является северной границей распространения светлогумусовых почв. На равнинах данной области сформировались черноземы текстурно-карбонатные и каштановые почвы. Каштановые гидрометаморфизованные почвы распространены в понижениях в условиях повышенного поверхностного и грунтового увлажнения. Светлогумусовые почвы встречаются на волнисто-увалистых равнинах. Черноземы дисперсно-карбонатные развиты на карбонатном элюво-делювии и элювии. Черноземы в основном сформировались в условиях низкогорного рельефа. Иногда они встречаются в подгорных равнинах.

В Хангайских горах выделяется таежно-лесной почвенный пояс. Выше 20002200 м над ур. м. (верхняя граница леса) происходит переход к типичному высокогорному ландшафту. Петроземы, литоземы и карбо-литоземы преобладают в нивальных расчлененных ландшафтах. Торфянокриоземы и криоземы (грубогумусовые) развиты у верхней границы леса в подголь- 
цовом поясе. Почвы таежных ландшафтов нередко длительно, сезонно, и многолетнемерзлотные. Криоземы, подбуры и темногумусовые почвы сформировались под таежной растительностью Монголии. Подзолистый процесс в почвах Монголии наблюдается очень редко. На крутых южных склонах в межгорных понижениях среди горной тайги расположены «острова» почв под степной растительностью черноземного облика. В лесостепи светлохвойных и смешанных кустарничковых и травянистых фаций на 1650-1900 м над ур. м. южных склонов сопок и хребтов развиты темногумусовые метаморфизованные почвы. Серогумусовые почвы сформировались на карбонатных породах под древесными разнотравными сообществами.

На высотах 2100-2200 м Хэнтэйского нагорья выделяются участки горной тундры. Почвенный покров фрагментарен, прерывается частыми скальными выходами и осыпями с петроземами. Преобладающими типами почв являются литоземы грубогумусные, сопутствующими - глееземы и подбуры. В горно-таежном поясе Центрального Хэнтэя повсеместно распространена многолетняя мерзлота. Под кедрово-лиственничными, кедровыми и березово-сосновыми лесами развиты криоземы, сопутствующими являются подбуры. Небольшими участками встречаются торфяно-литоземы. В нижнем поясе лесной зоны значительные площади заняты подбурами и дерново-подбурами. Сопутствующими почвами являются серогумусовые.

На западной и южной периферийной частях Хэнтэйского нагорья на склонах северной экспозиции отмечается «оазисное» распространение очагов леса, березняка и субальпийских лугов с перегнойно-темногумусовыми почвами. Сохранение их связано с очаговым, локальным горно-покровным оледенением этой территории в период последнего сартанского оледенения (11-24 тыс. л). В нишах троговых долин сохранились «убежища» мерзлых грунтов. Благодаря метелевой концентрации снега и эффекту затененности на северных склонах отмечается положительный баланс влаги и обеспечиваются необходимые экологические условия для развития особей березы кустарниковой и лиственницы. Ниже по высотному уровню расположен пояс с темногумусовыми почвами. Каштановые, каштановые гидрометаморфизованные, темногумусовые метаморфи- зованные с темногумусовыми типичными и аллювиальными распространены по долинам рек в Юго-Западном Хэнтэе на территории низкогорья и среднегорья. Иногда на данной территории встречаются торфяные эутрофные почвы.

В Юго-Западном Прихубсугулье под высокогорной тундровой и горно-таежной растительностью развиты литоземы грубогумусовые, литоземы перегнойнотемногумусовые и темногумусовые, дерново-подбуры, в понижениях встречаются торфяные эутрофные и гумусово-гидрометаморфические почвы. В Восточном Прихубсугулье в условиях котловиннодолинного и высокогорного рельефа распространены литоземы грубогумусовые, литоземы темногумусовые, криоземы, дерново-подбуры, темногумусовые, встречаются торфяные эутрофные, аллювиальные и каштановые почвы.

В Северном Прихубсугулье под степной растительностью развиты каштановые почвы. Каштановые гидрометаморфизованные почвы формируются в условиях повышенного поверхностного и грунтового увлажнения в понижениях. На элювии и элюво-делювии карбонатных пород вместе с каштановыми почвами встречаются черноземы дисперсно-карбонатные маломощные щебнистые с укороченным профилем.

В ледниковых и речных долинах Забайкалья и Прибайкалья распространены аллювиальные гумусовые, темногумусовые, темногумусовые квазиглеевые, перегнойно-глеевые, торфяно-глеевые и аллювиально-слоистые почвы. На ледниковых отложениях северо-восточной окраины Иркутской области имеют распространение криоземы и торфяно-криоземы. Большие контуры торфяных эутрофных, аллювиальных торфяно-глеевых и перегнойно-глеевых почв расположены в молодых тектонических прогибах Хандинской, Предсаянской, Усть-Селенгинской депрессии. Они сформировались в горах, на плоскогорье, в дельтах рек в верховьях мелких рек. Засоленные почвы встречаются в долинах Куды, Манзурки и в Приольхонье.

В степной и сухостепной зонах Забайкалья, в поймах рек в основном преобладают аллювиальные светлогумусовые с контурами засоленных почв. Большие массивы аллювиальных перегнойнои темногумусовых почв расположены в дельте р. Селенга и в пойме р. Баргузин. 
Под болотной растительностью развиты торфяные эутрофные и торфяные эутрофные глеевые почвы. В местах разгрузки минерализованных вод очень широко распространены засоленные почвы (Алгинская, Харамодонская, Нухэ-Нурская и Кокуйская низменности).

В междуречье Джаргалант-Гол и Мунгарал-Гол, а также в прибрежной зоне оз. Хубсугул формируются почвы озерно-болотных комплексов и заболоченных лугов. Перегнойно-гидрометаморфические мерзлотные почвы имеют развитие в приозерной части впадин. В северной Монголии имеются небольшие контуры засоленных почв.

Разнообразие и специфичность условий почвообразования в бассейне оз. Байкал определяет самобытность почв. Это область распространения во всех высотных зонах маломощных неполнопрофильных почв отделов слаборазвитого, литоземов и органо-аккумулятивного. Очень важным диагностическим параметром являются поверхностные органогенные горизонты. Полнопрофильные почвы представлены в таежной зоне различными типами почв отделов криоземов, альфегумусового и структурно-метаморфического, в степной - аккумулятивно-гумусового, светлогумусового аккумулятивно-карбонатного, структурно-метаморфического, галоморфного. Разнообразие почв в поймах рек представлено почвами отделов аллювиального, слаборазвитого и галоморфного, а на болотах - преимущественно торфяного.

\section{Заключение}

Почвенный покров Байкальского региона и прилегающих Иркутской области и Забайкальского края наряду с общими фациальными и провинциальными особенностями имеет четкую вертикальную зональность, так как большая часть региона горная. Суровый климат региона обусловливает низкие темпы процессов химического и физического выветривания, слабую скорость почвообразования. Почвообразовательным процессом затронут слой от нескольких сантиметров до приблизительно полуметра. Во всех высотных зонах развиты маломощные неполнопрофильные почвы литоземов слаборазвитого и органо-аккумулятивного отделов. Полнопрофильные почвы распространены в степной зоне различными типами почв отделов аккумулятивно-гу- мусового, аккумулятивно-карбонатного, светлогумусового, структурно-метаморфического, галоморфного; в таежной зоне - альфегумусового и структурно-метаморфического и криоземов. Своеобразие условий почвообразования в бассейне оз. Байкал определяет самобытность почв. Например, формирование буроземов грубогумусовых в условиях Южного Прибайкалья.

Создание почвенной карты на территорию Байкальского региона и прилегающие Иркутскую область и Забайкальский край представляет собой важный этап в развитии почвенной науки России и Монголии. Эта карта может представлять основу для организации и управления природоохранной деятельности, учета земельных ресурсов.

Исследования проведень в рамках тем проектов НИР № АААA-А17-117041910169-4 (ФАHO 0347-2016-0002) u № AAAA-A17117011810038-7 (ФАНО 0337-2017-0002).

\section{Список литературы}

1. Экологический атлас бассейна озера Байкал/ А.Д. Абалаков, Э. Авирмэн, С.П. Алексеев [и др.]. - Иркутск: ИГ СО РАН, 2015. - 125 с.

2. Балсанова Л.Д. Диагностика лесных почв Селенгинского среднегорья / Л.Д. Балсанова, А.Б. Гынинова, В.М. Корсунов. - Рос. акад. наук, Сиб. отд-ние, Ин-т общей и эксперимент. биол. - Улан-Удэ: Изд-во БНЦ СО РАН, 2009. - 146 с.

3. Воробьева Г.А. Почва как летопись природных событий Прибайкалья: проблемы эволюции и классификации почв / Г.А. Воробьева. - Иркутск: Изд-во Иркутского госуниверситета, 2010. - 205 с.

4. Доржготов Д. Почвы Монголии / Д. Доржготов. Улан-Батор, 2003. - 370 с.

5. Доржготов Д. Почвы. Почвенно-географическое районирование Монголии / Д. Доржготов, О. Батхишиг // Национальный Атлас Монголии. - Улан-Батор, 2009. - С. 120-122.

6. Кузьмин В.А. Почвенный покров. Почвенное районирование Иркутской области / В.А. Кузьмин // Атлас Иркутской области, 2004. - С. 40-41.

7. Карта «Почвы бассейна озера Байкал». Масштаб 1:2500 000 / И.А. Белозерцева [и др.]. - Иркутск: ИГ СО PAH, 2015.

8. Почвы Бурятии: разнообразие, систематика и классификация / Л.Л. Убугунов [и др.] // Вестник Бурятской государственной сельскохозяйственной академии им. В.Р. Филиппова. - 2012. - № 2 (27). - С. 45-52.

9. Шишов Л.Л. Классификация и диагностика почв России / Л.Л. Шишов, В.Д. Тонконогов, И.И. Лебедева, М.И. Герасимова. - М.: Почвенный институт им. В.В. Докучаева PACXH, 2018. URL: http://soils.narod.ru/taxon/type/a. html (дата обращения: 07.08.2018)

10. Полевой определитель почв России. - М.: Почвенный институт им. В.В. Докучаева, 2008. - 182 с.

\section{References}

1. E’kologicheskij atlas bassejna ozera Bajkal / A.D. Abalakov, E`. Avirme`n, S.P. Alekseev [i dr.]. - Irkutsk: IG SO RAN, 2015. - 125 p.

2. Balsanova L.D. Diagnostika lesny`x pochv Selenginskogo srednegor'ya / L.D. Balsanova, A.B. Gy`ninova, V.M. Korsu- 
nov. - Ros. akad. nauk, Sib. otd-nie, In-t obshhej i e'ksperiment. biol. - Ulan-Ude': Izd-vo BNCz SO RAN, 2009. - 146 p

3. Vorob`eva G.A. Pochva kak letopis` prirodny`x soby`tij Pribajkal'ya: problemy' e'volyucii i klassifikacii pochv / G.A. Vorob 'eva. - Irkutsk: Izd-vo Irkutskogo gosuniversiteta, 2010. -205 p.

4. Dorzhgotov D. Pochvy' Mongolii / D. Dorzhgotov. Ulan-Bator, 2003. - 370 p.

5. Dorzhgotov D. Pochvy`. Pochvenno-geograficheskoe rajonirovanie Mongolii./ D. Dorzhgotov, O. Batxishig// Nacional`ny`j Atlas Mongolii. - Ulan-Bator, 2009. - P. 120-122.

6. Kuz’min V.A. Pochvenny`j pokrov. Pochvennoe rajonirovanie Irkutskoj oblasti / V.A. Kuz`min // Atlas Irkutskoj oblasti, 2004. - P. 40-41.
7. Karta «Pochvy` bassejna ozera Bajkal». Masshtab 1:2500 000 / I.A. Belozerceva [i dr.]. - Irkutsk: IG SO RAN, 2015 .

8. Pochvy' Buryatii: raznoobrazie, sistematika i klassifikaciya/ L.L. Ubugunov [i dr.] // Vestnik Buryatskoj gosudarstvennoj sel'skoxozyajstvennoj akademii im. V.R. Filippova. - 2012. - № 2 (27). - P. 45-52.

9. Shishov L.L. Klassifikaciya i diagnostika pochv Rossii / L.L. Shishov, V.D. Tonkonogov, I.I. Lebedeva, M.I. Gerasimova. - M.: Pochvenny j institut im. V.V. Dokuchaeva RASXN, 2018. URL: httr://soils.narod.ru/taxon/tyre/a.html (data obrashheniya: 07.08.2018)

10. Polevoj opredelitel pochv Rossii. - M.: Pochvenny`j institut im. V.V. Dokuchaeva, 2008. - 182 p. 